\title{
Research On the Teaching Management of University Based on TQM
}

\author{
Zhan-yan Liu \\ Office of Educational Administration \\ Hebei Finance University \\ Baoding,China
}

\begin{abstract}
With the development and expansion of social economy in our country, the quality of the society is becoming higher and higher. Colleges and universities in China has initially formed a relatively perfect teaching management system, but with the continuous development of higher education. Its existence many problems have been exposed more and more, and ultimately affect the improve the quality of teaching in colleges and universities. Firstly, this paper has combbed the university teaching management system theory and comprehensive quality management theory, then analysed the feasibility of comprehensive quality management mode which was introduced, lastly, discussed the train of thought for constructing the total quality management of teaching in China's universities from the perspective of theory and practice.
\end{abstract}

Keywords:Total quality management; Ordinary university; Teaching management

\section{Introduction}

The expansion of the scale of higher education in China has brought new opportunities and challenges to college teaching management. The constant expansion of higher education caused by the society and the education sector worry on the quality of education, the quality of higher education facing the severe test, to comprehensively strengthen the teaching quality management has become the colleges and universities in the popularization of higher education in the process of the inevitable choice. Quality is the life and soul of higher education, teaching is the center of the university management, therefore improving the quality of teaching is the core of university education, and improving the teaching management level is the premise and basis for improving the quality of teaching. In order to improve the quality of teaching, the teaching quality management must focus on the "center" of the teaching, and form a perfect theoretical system. For a long time, education only through a variety of physical resources input to measure changes in the benefit of running a school and quality of change, and management system of exclusion in quality assurance and improve, not as an important factor of inter-university differences. With the voice of "improve higher education teaching quality" rising, the teaching quality management becomes more and more imminent.

The quality of education has become the key link about China's strategy of revitalizing through science and education, therefore establish a sound and effective system of teaching quality management system of higher education to ensure that the main initiatives steady improvement in the quality of popularization. With the perfection of our country socialist market economy system, social of higher education talent training quality put forward higher requirements, in order to do a good job in the teaching management is a long-term construction and accumulation process, which aims to reform of college teaching quality management. In order to overcome the disadvantages of traditional management mode of education quality, better to improve higher education quality management and the quality of teaching, has become a wide topic of higher education research in China. 


\section{Overview of Total Quality Management Theory}

Total quality management was proposed by quality management master Feigenbaum in the 20th century 50's, and widely populared in the Japanese in the 1970s. In the early 1980s, some America enterprises brought it into management and made a rapid promotion, then several colleges and universities began to try to implement total quality management, also including some other countries. According to the relevant data show, only in 1991-1992 two years' time, "all or part of the implementation of total quality management in higher schools from 92 to 220 in America, even as Harvard university, Columbia university, university of Oregon. These colleges and universities experimental results has confirmed that total quality management to continuously improve the quality of higher education produced a positive effect, become the effective ways and means to ensure the quality of higher education.

At present, the concept of total quality management is still lack of uniform definition. In accordance with the definition of the international organization for standardization, total quality management is "refers to an organization to quality as the center, to full participation as the basis, for the purpose of through let customer satisfaction and the organization of all members and social benefit and achieve long-term success in management approach." Lewis believes that total quality management is a philosophy system, it can achieve the goal of organization directly, thus ensuring the customer's satisfaction and the maximization of the investors' benefit." Some scholars have pointed out that, the total quality management (TQM) is "refers to the continuous improvement using the choice of tools and techniques, training guided decision and action planning process, colleges and universities in various fields is being close to the optimal target." Although there are differences in the overall quality management, but the

In the University, the quality of teaching is the core of education quality, and the key to the quality of teaching lies in the management of teaching quality. Therefore, in the teaching quality management in Colleges and universities the student oriented, market demand oriented pattern of teaching quality management, in order to change that some concept of total quality management as a whole system and there is almost a consensus.

\section{The Basic Content of University Teaching Quality Management}

The definition of teaching quality management,scholars from different perspectives given a different definition. Feng Xuejun believes that teaching quality management is a complex structure system with specific contents and laws. From the perspective of horizontal structure, including teaching quality management, quality management of student's academic, educational quality management elements of the longitudinal structure from the point of view, including all stages of the process of teaching and learning and the main link; Wu Zhihong believes that the teaching quality management is through effective management, coordination and control, and promote the teaching effect to meet the requirements of the curriculum plan, the syllabus and the textbook; Zou min thinks "teaching quality management is to attach importance to the concept of teaching quality and as the basis, using scientific means to design the teaching work of the whole process, implementation, inspection, and analysis of the sense of responsibility of the quality, to ensure to achieve the teaching goal and the teaching task of a management mode. Analysis teaching quality, set up smooth information feedback network, to create and maintain a good educational environment and achieve the best teaching effect. Teaching quality management is a subsystem of teaching management, It has some common features with the teaching management, and the quality management of teaching has its own development and features. The characteristics of college teaching quality management are comprehensive, complexity, dynamic, relative and systematic coordination.

colleges and universities teaching quality is difficult to guarantee, teachers and students teaching difficult to mobilize the enthusiasm, it is difficult for the graduates to find a job and people and employ persons is hard to find the status of schools and the market closely, improve the quality of education and teaching in schools and students' 
ability to adapt to society. Therefore, the establishment of quality management system in colleges and universities should also to students for this, for the innovative talents training services, and carry out quality education, to cultivate students' innovation ability included in the teaching quality evaluation system to accurately grasp the market information,to formed a relationship of supply and demand.

\section{The Feasibility of TQM for College Teaching Quality Management}

\subsection{The Common Between Universities and Enterprises}

According to the terms, the education is classified into different levels and categories, and each has different characteristics. Among them, theoretical analysis and system of total quality management of teaching in China's universities established that it provides to the benefits of the actors themselves is far less than that provided for the benefit of society, its activities should not be market oriented and higher education because of its three major functions of the location, the school and enterprise business exist many common. In a certain sense, higher school as a production unit and its main work includes three aspects: firstly, development and to the community provide scientific and technological achievements; secondly, training and delivery of senior personnel; thirdly, provide services to the society, mainly science and technology service.

\subsection{Basic Principles of TQM for Teaching Management in Colleges}

The customer of university teaching management consists of two parts: internal customer and external customer. Government and the administrative department of education is the education of investors and managers, but with increase of family education investment proportion, as an education service buyers, students and parents more concerned about college teaching quality, so parents and students, especially parents pay more attention to the risk of investment in education. Therefore, the administrative departments of colleges and universities must fully aware of the purpose of education services, and on this basis, strengthen the service concept, students, parents and education administrative department needs and the needs of the society as to pursue the development of the center of gravity, outstanding students' subject status, respect for the personality development of students. If the teaching management in Colleges and universities can always take customer demand as the starting point and the end result, it can not only to improve the quality of education, lay a solid social foundation for the development of colleges and universities, but also will improve the utilization of limited resources, so as to improve the benefit of running a school. In this sense, in the university teaching management, the attention to the customer's demand is not only the survival and development needs of colleges and universities, but also the country and the society to educate the superintendent's earnest expectation.

\subsection{The Preliminary Results of TQM in University Teaching Management Practice}

There are also some educational institutions in our country to use TQM and ISO9001 standards. At present, according to the ISO9001 standards, the establishment of quality management system of the university mainly Tsinghua University, Dalian Maritime University, Harbin Institute of Technology, Zhejiang University, etc. Practice has proved that, they implemented a comprehensive quality management is successful, and achieved the following results:reference to enterprise's total quality management idea to build modern school management system, is conducive to the transformation and updating of school education idea and management concept, enhance school service consciousness; standardize the school teaching management, and gradually establish and perfect continuous quality improvement of teaching management system; improve the school's reputation and visibility, increase funding for students and education, to reduce the cost of education, optimize the allocation of resources, reduce the risk of education investment; greatly improve the teaching quality, enhance the satisfaction of students, parents, society, government and education administrative department. 


\section{New Thinking of TQM in Colleges and Universities}

The introduction of the concept of TQM to the teaching management in colleges and universities is to focus our attention on the teaching of colleges and universities. Comprehensive management and improvement of college teaching management and related activities, establish a "customer centered" educational service view, so that the work of colleges and universities around the teaching management to form a complete service network, from improve the quality and efficiency of education in colleges and universities. Our country universities introduce the idea of total quality management to improve education. The quality of teaching, the cultivation of high-quality personnel, and the improvement of the status quo of the teaching management system in colleges and universities, are have profound theoretical and practical significance.

\subsection{Follow the PDCA Circulation}

The ultimate goal of management is to optimize the work.Scientists Deming according to the objective law of management summed up the management operation procedures of PDCA cycle. Practice has proved that this management approach is effective. In Colleges and universities, the whole school teaching management,which is a large PDCA cycle, each department is a small PDCA cycle, it has its own cycle.

\subsection{The Importance of University Leaders}

Deming once said, "management class is not the job of supervision, but leadership". there is a lack of leadership in organization, then the process can not be sustained. If the total quality management of the education is to be successful, it must be handed over to the leader who has a decisive and clear goal to complete the education. Therefore, university leaders must attach great importance in terms of ideology, strengthen their awareness of management, take the lead in studying TQM theory. Secondly, the manager should pay attention to the long-term planning of school teaching management, and become the promoter and the body of the planning and execution. Again, the management of colleges and universities to establish the correct values and reasonable treatment of scale, efficiency and development, emphasizes the concept of consistent quality and efficiency, and scale efficiency. Lastly, pay more attention to the interpersonal communication between faculty and staff, and believe that everyone has unlimited development space.

\subsection{Encourage the Full Active Participation}

In the teaching and management, the full participation of the staff involved in two aspects: firstly, everyone should participate in it. Faculty and students is the school organization, only their full participation to make their genuine talent into full play, so as to bring innovation to improve schools and educational reform on the quality; secondly, it is need to participate fully, the leader should provide the subordinate with the internal environment that can fully participate and exert the initiative, so as to mobilize the enthusiasm of the person and the cadres at all levels.Only in the full empowerment of the staff will have a strong sense of quality, professionalism and responsibility. Only in this way can it help to maximize the mobilization of staff participation and initiative, so as to school development brainstorming. At the same time, the universities should make a system training. Through this training, teachers can improve the degree of education, so as to get more work opportunities and find their more potential.

\section{Conclusion}

Improving teaching quality is the eternal theme of higher education. To strengthen the management and control of teaching quality is an important guarantee to improve the quality of higher education. It is one of the important tasks of higher education to strengthen quality control and management. The expansion of the scale of higher education is an inevitable trend, in the development of the number at the same time, we must guarantee to improve the quality of development and, its essence is the development quality of continuity, integrity, equality and coordination. That is to say quality is a prerequisite for achieving sustainable development of higher education. Therefore, the higher education as a social investment huge business, we must use the advanced management ideas and methods to ensure the quality and improve efficiency.

To achieve higher healthy, stable and sustainable 
development, we should improve the level of teaching management, to strictly control the various factors affecting the quality of teaching by total quality management concept and mode, and constantly improve the quality of education and teaching.

Teaching management in colleges and universities in application and reference to total quality management ideas and methods should be targeted, and should grasp the essence of total quality management ,that is continuous improvement. In colleges and universities, we should start from the concrete national conditions of our country, change education idea, renew teaching management concept; Always we should focus on the teaching management of the overall goals, fully realize the aim of the education service, highlight the students' subjectivity, respect students' personality development; meanwhile, according to the PDCA circulation, adhere to the pursuit of teaching quality as a starting point, based on facts and analysis of the form or the environment, ensuring the correctness, suitability and feasibility of the decision-making. Finally realizes the fundamental shift of teaching management in colleges and universities, to ensure the continuous improvement of teaching quality of higher education.

\section{References}

[1]. Jin Hexiang. Theoretical Analysis and System Construction on Teaching Total Quality Management of College and University in China[D].Lanzhou University, 2007.

[2]. Ge Jing. Research on the Possibility of Total Quality Management of Teaching in China's Universities[D].Suzhou university, 2006.

[3]. Tang Daguang. Total Quality Management: important ideas of university quality management [J].University, 2014(7): pp43-46.

[4]. Zhou Caiyun. Research On the Reform of Teaching Management Based on Total Quality Management [J]. Contemporary Education Forum (comprehensive study), 2011(6): pp77-79. 